\title{
First report of Verticillium dahliae causing verticillium wilt on Stevia rebaudiana in Europe
}

\author{
Daniele Da Lio ${ }^{1}$. Luigi De Martino ${ }^{1}$. Silvia Tavarini ${ }^{1}$ - Barbara Passera ${ }^{1}$ - Luciana Gabriella Angelini ${ }^{1}$. \\ Giovanni Vannacci ${ }^{1} \cdot$ Sabrina Sarrocco ${ }^{1}$
}

Received: 30 March 2018 / Accepted: 13 June 2019 / Published online: 1 July 2019

(C) Società Italiana di Patologia Vegetale (S.I.Pa.V.) 2019

Keywords Verticillium dahliae $\cdot$ Wilt $\cdot$ Stevia rebaudiana

Stevia rebaudiana Bertoni (Asteraceae) is an herbaceous perennial plant from Paraguay, mainly cultivated for its nocalorie sweetening compounds (steviol glycosides). The increasing market demand for steviol glycosides provides a strong incentive to cultivate this species beyond the traditional production zones (Angelini et al. 2017).

In May 2017, several S. rebaudiana plants cultivated in a field at the Experimental Centre of DAFE (Pisa, Italy; $43^{\circ} 40^{\prime} \mathrm{N} ; 10^{\circ} 19^{\prime} \mathrm{E}$ ) showed symptoms of a vascular disease, i.e. a rapid branch dieback which, eventually, led to plant death.

Stems of symptomatic plants were cut in small pieces, surface sterilized, placed on PDA with streptomycin sulfate $(100 \mathrm{ppm})$ and grown at $25{ }^{\circ} \mathrm{C}$ (12-h light period). Colonies, developed from pieces, appeared concentric, slow growing, becoming dark with age on PDA. Microscopic observations revealed the presence of verticillate shaped conidiophores, of hyaline, smooth walled, non (rarely 1) septate, cylindrical with rounded apices to oval (3.0-) $5.5(-9.2) \times(2.2-) 3.2(-4.0) \mu \mathrm{m}$ lengh $\mathrm{x}$ width conidia and of $50-150 \mu \mathrm{m}$ diameter microsclerotia.

To confirm morphological identification, total gDNA was extracted from a monoconidial colony (NU1A) and the ITS was amplified by PCR using primers ITS5/ITS4 (White et al. 1990). The resulting amplicon was sequenced using the same primers. The sequence was blasted, thus resulting $100 \%$ identical to the ITS sequence of the holotype Verticillium dahliae strain

Daniele Da Lio

daniele.dalio@hotmail.com

1 Department of Agriculture, Food and Environment (DAFE), University of Pisa, Via del Borghetto 80, 56124 Pisa, Italy
PD322 (Accession No. HQ206718.1; Inderbitzin et al. 2011) and deposited in GenBank (Accession No. MG851988).

Koch's postulates were verified on $S$. rebaudiana plants by inoculating roots with a conidial suspension $\left(10^{6}\right.$ conidia $\left.\mathrm{ml}^{-1}\right)$ obtained from NU1A. Water inoculated plants were used as control. After ten days of incubation at $25{ }^{\circ} \mathrm{C}$, symptoms of tracheomicosis were registered, resulting identical to those observed in field. Fungal colonies re-isolated from the lesions appeared morphologically identical to the original isolate.

This is the first report of $V$. dahliae wilt on $S$. rebaudiana in Europe. As far as we know, the presence of this pathogen on $S$. rebaudiana was only reported in North America.

\section{References}

Angelini LG, Martini A, Passera B, Tavarini S (2017) Cultivation of Stevia rebaudiana Bertoni and associated challenges. In: Merillon J-M, Ramawat KG (eds) Sweeteners. Springer International Publishing, Switzerland, pp 1-52

Inderbitzin P, Bostock RM, Davis RM, Usami T, Platt HW, Subbarao KV (2011) Phylogenetics and taxonomy of the fungal vascular wilt pathogen Verticillium, with the descriptions of five new species. PLoS One 6(12):e28341. https://doi.org/10.1371/journal.pone.0028341

White TJ, Bruns T, Lee S, Taylor J (1990) Amplification and direct sequencing of fungal ribosomal RNA genes for phylogenetics. In: Innis MA, Gelfand DH, Sninsky JJ, White TJ (eds) PCR protocols: a guide to methods and applications. Academic Press, San Diego, pp $315-322$

Publisher's note Springer Nature remains neutral with regard to jurisdictional claims in published maps and institutional affiliations. 